\title{
PHYSIC NUT (JATROPHA CURCAS L.) DISEASES IN LAMPUNG PROVINCE
}

\author{
CIPTA GINTING and TRI MARYONO \\ Department of Plant Protection, University of Lampung \\ Bandar Lampung 34145, Indonesia
}

\begin{abstract}
Intensified cultivation of physic nut (Jatropha curcas L.) could raise the importance of plant diseases. The objectives of this research were to diagnose diseases occurring on physic nut in Lampung Province and to determine their intensity. Field observation was conducted in four districts: South Lampung, Tanggamus, Bandarlampung, and Tulang Bawang. Disease intensity, whether expressed as disease incidence or severity, was recorded from plant samples determined by making diagonal lines across the field on which five observation spots were made. On each spot, five plant samples were observed. Specimens were also collected and placed individually in plastic bags for laboratory observation. The diseases found on physic nut in Lampung Province were cercospora leaf spot, alternaria leaf spot, fusarium wilt, and bacterial wilt. In addition, leaf malformation first thought to be viral disease was commonly found in many locations. Further mechanical transmission failed to produce similar symptom on tested plants and higher population of mites were found on malformed leaves than that in normal leaves. Based on the disease distribution and intensity, the most likely threatening disease in physic nut cultivation is bacterial wilt. Fusarium also caused wilt, but it was only found in one subdistrict with low incidence.
\end{abstract}

Key words: Alternaria, Cercospora, fusarium wilt, bacterial wilt, Jatropha curcas diseases

\section{INTRODUCTION}

Recently, efforts to develop and utilize alternative energy sources have been increasing due to the need to meet energy demand and to reduce the dependence on fossil energy sources. Utilizing plants as alternative sources is a priority because of being renewable energy resources. Physic nut (Jatropha curcas L.) is one of the prospective plants. It can grow on soil with medium and low fertility, its oil is inedible and of high quality for fuel (Sudradjat 2006; Syah 2006).

Physic or also known as "jarak pagar" in Indonesia is used to be grown less intensive such as for fence. In the last few years, however, physic nut has been cultivated intensively in a monoculture pattern. For example, in Katibang subdistrict, South Lampung district, alone the acreage of physic nut was 192 ha (Anon. 2007a). Furthermore, the head of Mining and Energy Department of Lampung Province stated that the potential area for physic nut planting in Lampung Province is about 5000 ha (Anon. 2007b). Banuwa (2007) also reported that Lampung Province has a good prospect to grow jatropha. 
Change of planting pattern could increase the importance of some plant diseases. Intensification of a plant generally tends to increase the threat of pests and diseases (Fry 1982; Agrios 2005). Plants that are grown less intensive usually do not suffer severely from pests and pathogen attack. However, when they are cultivated intensively such as in intensive monoculture pattern, plants are of high risk to be attacked severely by pests and diseases, especially when they are not properly managed.

Accordingly, the change in cultivation pattern of physic nut into intensive monoculture pattern should be followed by raising awareness about its pests and diseases. Information about physic nut diseases in literature is very limited. Lozano (2007) listed pathogens infecting the plant without mentioning their geographical distribution, including Phytophthora spp., Pythium spp., and Fusarium spp., Heminthosporium tetramera, Pestalotiopsis paraguarensis, P. versicolor, and Cercospora sp. It has also been reported that several pathogens infect physic nut in Indonesia: Ralstonia solanacearum, Rhizoctonia bataticola (Republic of Indonesia Department of Agriculture 2006a), Phytophthora nicotianae (Republic of Indonesia Department of Agriculture 2006b), Alternaria sp. and Cercospora sp., Fusarium sp., Botrytis and Xanthomonas campestris (Hambali et al., 2006; Prihandana and Hendroko 2006). Latha et al. (2009) reported the occurrence of root and collar rot diseases of physic nut in India.

To our knowledge, there is no published information on diseases of physic nut in Lampung Province so far. The objectives of this research were to diagnose diseases occurring on physic nut in Lampung Province and to determine the intensity of the disease in the field.

\section{MATERIALS AND METHODS}

\section{Observation in the field}

The disease diagnosis started with field observation of physic nut diseases. Field observation was conducted in four districts, considered to be the most important areas of physic nut cultivation in Lampung, and in each district two subdistricts were visited. The districts and subdistricts were South Lampung (Natar and Ketibung subdistricts), Tanggamus (Gunung Alip and Talang Padang), Bandarlampung (Rajabasa and Tanjung Seneng), and Tulang Bawang (Tanjung Raya and Simpang Pematang). Due to wide geographical distribution of physic nut fields, some fields were only visited once or twice. Observation was focused on symptoms of diseases as they occur in the field and factors that might affect the diseases such as plant age, plant spacing (row width), plant growth, plant canopy, and topography.

To determine the intensity of diseases, plant samples were selected with the following procedure. Two diagonal lines were made across the field on which five observation spots were made. On each of five spots (x) five plants were observed.

For systemic diseases, the disease intensity was expressed as disease incidence determined by using the formula of DI $=\mathrm{n} / \mathrm{N} \times 100 \%$, where $\mathrm{DI}=$ disease incidence, $\mathrm{n}=$ number of plants showing symptoms, and $\mathrm{N}=$ the total number of plants observed. 


$$
\mathrm{DS}=\frac{\sum_{\mathrm{i}}^{\mathrm{n}}(\mathrm{v} \times \mathrm{n})}{\mathrm{V} \times \mathrm{N}}
$$

For local diseases, the disease intensity was expressed as diseases severity determined by the formula of where DS = disease severity, $\mathrm{v}=$ disease score of sample $\mathrm{i}^{\text {th }}, \mathrm{n}=$ number of plant samples with a particular score, $\mathrm{V}=$ the highest score, and $\mathrm{N}=$ total number of samples. Disease score range from 0 (no symptom) to 4 (more than $50 \%$ of leaf surface showed symptoms).

Regarding the kinds of the diseases, in addition to the plant samples, any plants showing symptoms were observed. At first the distribution of diseased plants was determined whether it was evenly distributed in the field or it was in clustered (made gradient). Then, for each diseased plant it was determined whether the symptoms were local or systemic. Specimens, whole or part of plant samples showing symptoms, were collected and placed individually in plastic bags. The specimens were placed in a cooler during transportation to the laboratory for further examination.

\section{Observation in the Laboratory}

Each of the specimens was observed in the laboratory soon upon arrival or the next day. If the suspected pathogen causing particular symptoms was a fungus, the specimen was incubated at relative humidity of $100 \%$ by placing sterile cotton dampened with sterile water in plastic bags or trays covered with plastic. Pathogenic fungi usually form spores in $2-3$ days at room temperature. The spores and other structures were observed with a compound microscope.

Some other specimens were used to isolate infecting fungi. For this purposes, the media used was potato dextrose agar (PDA) supplemented with lactic acid $1.4 \mathrm{ml}$ per liter media. Small pieces $(1-2 \mathrm{~mm})$ of plant tissue between the healthy and the infected tissue were taken and then placed on the media in Petri dishes. Fungi growing in the media was transferred into new media and identified to genus. Identification was based on Barnett and Hunter (2001).

Diseased plants suspected to be infected by virus was diagnosed from the symptoms. To verify whether or not the causal agent was a virus, the suspected agent was transmitted mechanically. Further observation was also conducted to determine whether causal agent other than virus might cause the symptoms. On the malformed leaves, mites were found. To determine whether or not the severity of leaf malformation was correlated to the population of mites, the leaves were divided into three groups, i.e.: leaves with severe symptoms, leaves with mild symptoms, and those without symptoms. From each category, the number of mites was determined.

If the symptom was suspected to be caused by pathogenic bacteria, diagnosis was based on internal and external symptoms. In addition, effort was made to observe bacterial ooze. To do this, a few steam cuts were placed on test tubes containing tap water. About 30 minutes later, bacterial ooze was streaming out of the tissue. 


\section{RESULTS AND DISCUSSIONS}

\section{Locations and Cultivation Manners}

Table 1 summarizes the locations and cultivation manners of physic nut fields in four districts. It shows that the cultivation system including plant age, row width, and planting pattern was similar in the subdistricts of every district. However, the cultivation system greatly varied among districts. The area used for physic nut cultivation is generally flat except that of Ketibung, South Lampung. Physic nut was cultivated in a monoculture system in all fields except in Tulang Bawang district where it was grown in mixed culture with rubber and oil palm plants. Physic nut generally grew well except in both fields of Tulang Bawang district and Tanjung Seneng where it grew poorly.

In Bandarlampung, only two physic nut fields were found and those were in Rajabasa and Tanjung Seneng subdistricts. In addition to these two fields, there were a few locations where seedlings are produced for sale.

In Tulang Bawang district, three fields were reported to be planted with physic nut. However, when we visited the locations it appeared that one field was grown with another Jathropa species locally known as "jarak kepyar". Therefore, only two fields about 0.5 ha, each was observed which are located in Tanjungraya and Simpang Pematang subdistrits.

Table 1. Locations and cultivation manners of physic nut in the field observed in four districts in Lampung Province

\begin{tabular}{|c|c|c|c|c|}
\hline \multirow[t]{2}{*}{ Locations } & \multicolumn{4}{|c|}{ Cultivation Manners } \\
\hline & $\begin{array}{l}\text { Plant Age } \\
\text { (months) }\end{array}$ & $\begin{array}{l}\text { Row width } \\
\text { (m) }\end{array}$ & Planting pattern & $\begin{array}{c}\text { Land } \\
\text { condition }\end{array}$ \\
\hline \multicolumn{5}{|l|}{ South Lampung District: } \\
\hline Natar Subdistrict & 8 & $2 \times 2$ & monoculture & flat \\
\hline Ketibung Subdisrict & 9 & $2 \times 2$ & monoculture & aslant \\
\hline \multicolumn{5}{|l|}{ Tanggamus District: } \\
\hline Gunung Alip Subdistrict & 6 & $1 \times 1$ & monoculture & flat \\
\hline Talang Padang Subdisrict & 6 & $1 \times 1$ & monoculture & flat \\
\hline \multicolumn{5}{|l|}{ Bandarlampung District: } \\
\hline Rajabasa Subdistrict & 6 & $1 \times 1$ & monoculture & flat \\
\hline Tanjung Seneng Subdisrict & 12 & $1 \times 1.25$ & monoculture & flat \\
\hline \multicolumn{5}{|l|}{ Tulang Bawang District: } \\
\hline Tanjung Raya Subdistrict & 2 & $1 \times 1.25$ & $\begin{array}{l}\text { mixed culture with rubber } \\
\text { plants }\end{array}$ & flat \\
\hline Simpang Pematang Subdisrict & 2 & $1 \times 1.25$ & $\begin{array}{l}\text { mixed culture with oil } \\
\text { palm plants }\end{array}$ & flat \\
\hline
\end{tabular}

\section{Physic Nut diseases}

The disease and disorder of physic nut found in Lampung were cercospora leaf spot, bacterial wilt, alternaria leaf spot, fusarium wilt, and leaf malformation (Table 2). Cercospora leaf spot was found in all fields except in Tanjung Seneng, Bandarlampung. The diagnosis of cercospora leaf spot was conducted by field observation followed by 
laboratory examination. The form of leaf spot was irregular. The leaf spot was whitish brown in the center with brown at the edge. The spot was a necrotic tissue that was encircled by chlorotic tissue seen as yellowish zone (Figure 1). In the laboratory, fungal reproductive structure taken from the leaf spot was identified as Cercospora based on the identification key used (Barnett and Hunter 2001). Cercospora is reported to cause such leaf spot on physic nut and the species is reported to be C. ricinella (Hambali et al. 2006) and C. jatrophae (Prihandana and Hendroko 2006). Based on this observation and reference, it was concluded that the disease was cercospora leaf spot caused by Cercospora sp.

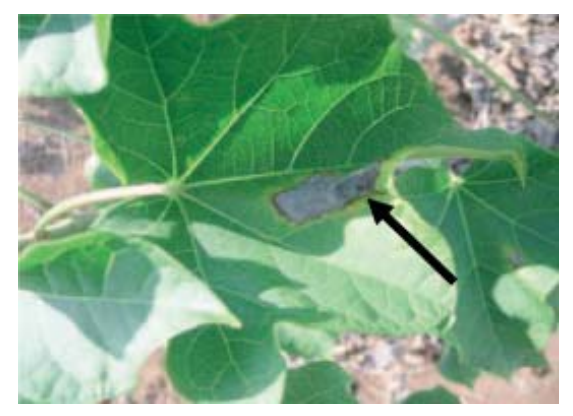

Figure 1. Symptom of cercospora leaf spot. The symptom was described in the teks.

Alternaria leaf spot was found only in Tanjung Seneng. Diagnosis of alternaria leaf spot was also conducted in the field and confirmed in the laboratory. The symptoms of this disease are similar to that of cercospora leaf spot except that all spot areas are brown in color without whitish area (Figure 2). In addition, after 2-day incubation at $100 \%$ relative humidity at room temperature, conidia were found in the spot area. The conidia consisted of several dark cells. According to the identification key (Barnett and Hunter 2001), the conidia were formed by Alternaria. Alternaria ricini was reported to be the causal agent of leaf spot of physic nut (Hambali et al. 2006). Based on the observation in the field and in the laboratory by Hambali et al. (2006), it was concluded that the disease was alternaria leaf spot caused by Alternaria sp.

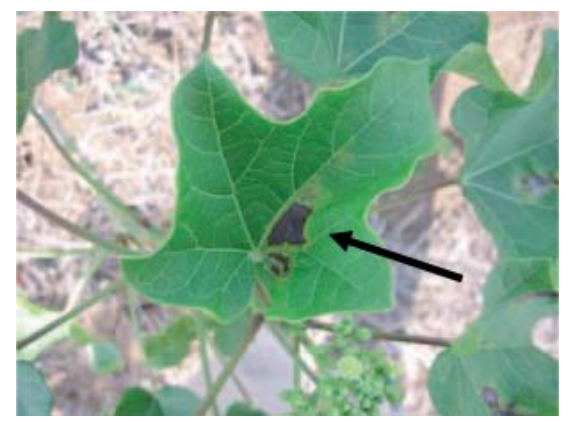

Figure 2. Symptom of alternaria leaf spot (arrow). 
Another disease of physic nut was wilt caused by a fungus, Fusarium. The disease was only found in Tanjung Raya Subdistrict, Tulang Bawang District. The symptoms of the disease were the affected plant became wilt and the leaves remained attached to the plants. Isolation was done on PDA containing lactic acid $(1.4 \mathrm{ml} / \mathrm{l})$ media and the resulted culture was whitish in color. Observation under a microscope revealed that there were two kinds of conidia, i.e.: macroconidia and microconidia. According to Barnett and Hunter 2001, the fungus is Fusarium. Hambali et al. (2006) reported that F. oxysporum could cause wilt symptoms in physic nut in the seedbeds as well as in the field.

Bacterial wilt was found at least in one subdistrict of all districts in Lampung Province (Table 2). The main symptoms were that the affected plants became wilted and the leaves remained attached to the plants. The base stem showed necrosis. Internal observation revealed that the internal tissues showed brownish color in the middle parts (Figure 3). When the stem was submerged in tap water, bacterial ooze streamed out of the plant tissue. The bacterial ooze looked like white strand but when the water was shaking the bacterial ooze soon broke and the suspension became clouded. Based on the external and internal symptoms as well as the bacterial ooze, it was assumed that the disease was bacterial wilt caused by Pseudomonas (Ralstonia).

In addition to the diseases, a disorder called leaf malformation was observed on the leaves, mostly on the young ones. Leaf malformation occurred in all fields except the fields in Tulang Bawang district. It was thought to be caused by a plant virus because several plants showed similar symptoms when attacked by certain plant viruses (Agrios 2005; Semangun 2000). Some farmers also believe that the problem was caused by a virus. However, mechanical transmission failed to give positive results that the inoculated plants did not show any symptom after more than 4 weeks after inoculation. Since no symptoms occur in the tested plants indicating that the agent could not be transmitted mechanically, further observation was conducted in two fields which were Natar and Rajabasa subdistricts. During 5-week observation in both fields, some plants showed reduced symptoms and the incidence of leaf malformation was decreased (Table 2). Furthermore, it was observed that mites were found to be associated with the disordered plants. When the population of mite was determined on leaves with severe, mild, and no symptoms, it was consistently found that mite population on leaves with symptoms was higher than that on leaves without symptoms (Table 3).

Table 2. Locations, diseases, and disease intensity of physic nut

\begin{tabular}{|c|c|c|c|c|c|c|}
\hline \multirow{2}{*}{$\begin{array}{c}\text { Locations } \\
\text { (Date of First Observation) }\end{array}$} & \multirow[t]{2}{*}{ Diseases } & \multicolumn{5}{|c|}{$\begin{array}{c}\text { Disease Intensity (\%) at } \\
1-5 \text { Observations }{ }^{1)}\end{array}$} \\
\hline & & 1 & 2 & 3 & 4 & 5 \\
\hline \multicolumn{7}{|l|}{ South Lampung District: } \\
\hline $\begin{array}{l}\text { Natar Subdistrict } \\
\text { (6 Juni 2007) }\end{array}$ & $\begin{array}{l}\text { Cercospora leaf } \operatorname{spot}^{2)} \\
\text { Bacterial wilt } \\
\text { Leaf malformation }\end{array}$ & $\begin{array}{c}22 \\
7 \\
98\end{array}$ & $\begin{array}{c}17 \\
4 \\
84\end{array}$ & $\begin{array}{c}13 \\
2 \\
58\end{array}$ & $\begin{array}{c}6 \\
-4) \\
44\end{array}$ & $\begin{array}{c}6 \\
- \\
33\end{array}$ \\
\hline $\begin{array}{l}\text { Ketibung Subdisrict } \\
\text { (8 Oktober 2007) }\end{array}$ & $\begin{array}{l}\text { Cercospora leaf spot } \\
\text { Leaf malformation }\end{array}$ & $\begin{array}{l}10 \\
66 \\
\end{array}$ & $\begin{array}{c}9 \\
56\end{array}$ & - & - & $\begin{array}{l}- \\
-\end{array}$ \\
\hline \multicolumn{7}{|l|}{ Tanggamus District: } \\
\hline $\begin{array}{l}\text { Sinar Banten Subdistrict } \\
\text { (3 September 2007) }\end{array}$ & $\begin{array}{l}\text { Cercospora leaf spot } \\
\text { Bacterial wilt } \\
\text { Leaf malformation }\end{array}$ & $\begin{array}{l}20 \\
12 \\
80 \\
\end{array}$ & $\begin{array}{l}- \\
- \\
-\end{array}$ & $\begin{array}{l}- \\
- \\
-\end{array}$ & $\begin{array}{l}- \\
- \\
-\end{array}$ & $\begin{array}{l}- \\
- \\
-\end{array}$ \\
\hline
\end{tabular}


Table 2. Continued

\begin{tabular}{|c|c|c|c|c|c|c|}
\hline \multirow{2}{*}{$\begin{array}{c}\text { Locations } \\
\text { (Date of First Observation) }\end{array}$} & \multirow[t]{2}{*}{ Diseases } & \multicolumn{5}{|c|}{$\begin{array}{c}\text { Disease Intensity }(\%) \text { at } \\
1-5 \text { Observations }{ }^{1)}\end{array}$} \\
\hline & & 1 & 2 & 3 & 4 & 5 \\
\hline \multirow{3}{*}{$\begin{array}{l}\text { Talang Padang Subdisrict } \\
\text { (3 September 2007) }\end{array}$} & Cercospora leaf spot & 21 & - & - & - & - \\
\hline & Bacterial wilt & 32 & - & - & - & - \\
\hline & Leaf malformation & 40 & - & - & - & - \\
\hline \multicolumn{7}{|l|}{ Bandarlampung District: } \\
\hline \multirow{3}{*}{$\begin{array}{l}\text { Rajabasa Subdistrict } \\
\text { (3 Juni 2007) }\end{array}$} & Cercospora lealf spot & 22 & 22 & 17 & 25 & 25 \\
\hline & Bacterial wilt & 12 & 12 & 12 & 16 & 20 \\
\hline & Leaf malformation & 84 & 84 & 52 & 40 & 36 \\
\hline \multirow{2}{*}{$\begin{array}{l}\text { Tanjung Seneng Subdisrict } \\
\text { (7 Agustus 2007) }\end{array}$} & Alternaria leaf $\operatorname{spot}^{2)}$ & 4 & 5 & - & - & - \\
\hline & Leaf malformation & 96 & 88 & - & - & - \\
\hline \multicolumn{7}{|l|}{ Tulang Bawang District: } \\
\hline \multirow{2}{*}{$\begin{array}{l}\text { Tanjung Raya Subdistrict } \\
\text { (19 Juni 2007) }\end{array}$} & Cercospora leaf spot & 5 & 4 & 3 & - & - \\
\hline & Fusarium wilt ${ }^{3)}$ & 8 & 6 & 5 & - & - \\
\hline \multirow{2}{*}{$\begin{array}{l}\text { Simpang Pematang Subdisrict } \\
\text { (1 Oktober 2007) }\end{array}$} & Cercospora leaf spot & 3 & 2 & 1 & - & - \\
\hline & Bacterial wilt & 13 & 11 & 9 & - & - \\
\hline
\end{tabular}

Note:

${ }^{1)}$ Obervation was conducted $1-5$ times. In any field observed more than once, the observation interval was 2 week.

${ }^{2)}$ Cercospora leaf spot and alternaria leaf spot were expressed as disease disease severity. The formulas used to determine disease severity is stated in Materials and Method.

${ }^{3}$ B Bacterial wilt, fusarium wilt, and leaf malformation were expressed as disease incidence. The formulas used to determine disease intensity are stated in Materials and Method.

4) - means no data.

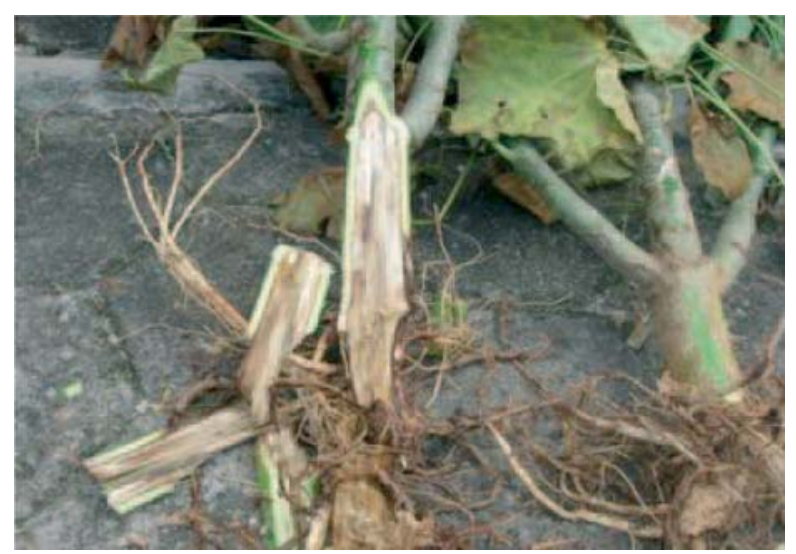

Figure 3. Part of wilted physic nut and longitudinal section of stem revealed brownish internal tissues showed. 
Table 3. Population of mites on leaves with or without symptom at two subdistricts

\begin{tabular}{cccc}
\hline Observation & \multicolumn{3}{c}{ Total number of mites per 25 leaves } \\
\cline { 2 - 4 } Spots $^{1}$ & Severe Symptom & Mild Symptom & No Symptom \\
\hline Natar Subdistricts & 25 & 16 & 7 \\
1 & 34 & 30 & 5 \\
2 & 25 & 30 & 8 \\
3 & 15 & 18 & 4 \\
4 & 19 & 25 & 6 \\
5 & 23.6 & 23.8 & 6.0 \\
Average & & & 5 \\
1 & 24 & 16 & 7 \\
2 & 33 & 30 & 7 \\
3 & 25 & 23 & 6 \\
4 & 19 & 15 & 4 \\
5 & 18 & 11 & 5.8 \\
\hline Rajabasa Subdistricts & 23.8 & 19.0 & 5 \\
\hline
\end{tabular}

${ }^{1)}$ On each observation spot, 25 leaves of each category were observed.

\section{Intensity of physic nut Diseases}

Disease intensity was determined by two methods, disease severity and disease incidence, according to the kind of diseases. Disease severity was used for diseases local in nature such as leaf spot and disease incidence was used for systemic in nature such as wilt diseases and leaf malformation.

Table 2 shows that disease severity of cercospora leaf spot on physic nut was low at Tulang Bawang district where the plants were 2 months old. In the other three districts, where physic nut was $6-12$ months old, the disease severity was relatively higher than that in Tulang Bawang. Based on the severity of cercospora leaf spot and its distribution almost all fields were contaminated by the disease. More attention should be paid to the diseases of physic nut cultivation.

Alternaria leaf spot was only found in Tanjung Seneng subdistrict and its severity was $4-5 \%$ (Table 2). Based on the results, it could be concluded that alternaria leaf spot is unlikely to be the major disease of physic nut.

Fusarium wilt was found only in Tanjung Raya subdistrict, Tulang Bawang district. Its incidence was $5-8 \%$ (Table 2). Based on the incidence its occurrence was relatively low, so the fusarium wilt could be regarded as a minor disease of physic nut. Since it causes wilt that is very destructive, the disease including factors affecting disease development and transmission should be monitored.

At locations where disease intensity was measured more than once with 2 week interval, disease intensity was either remained constant or tended to decrease overtime except alternatia leaf spot. It should be noted that, the observation was made started on May 2007 when the relative humidity was relatively high, and then it was decreasing during the period of observation. Based on the data, wilting diseases (fusarium wilt and bacterial wilt) also tended to decrease. The decrease was partly due to destructive 
observation that some wilted plants were taken and brought to the laboratory for further observation. These uprooted plants were not counted at subsequent field observation.

The most likely to be controlled in physic nut cultivation is bacterial wilt which is suspected to be caused by Pseudomonas (Ralstonia) solanacearum. The disease was found in all districts visited. Its incidence was $2-7 \%$ in Natar subdistrict, $9-13 \%$ in Simpang Pematang subdistrict, and $12 \%$ and $32 \%$ in Gunung Alit and Talang Padang subdistricts, respectively (Table 2 ). In addition, it causes wilt so that the disease potentially devastates the plants. According to the facts gathered from this study, it is interesting to note the recovery phenomenon shown by a plant. The plant wilted as a result of attack by Pseudomonas solanacerum. However, few months later, the plant recovered. One tends to assume that the recovery phenomena found in bacterial case might be due to the dry condition. This phenomenon needs to be studied further to determine the factor involved. Information obtained from this study is relevant to formulate disease control strategy.

The observation was conducted during the dry season in Lampung Province so that relative humidity was low. Relative humidity is an important environmental factor affecting disease incidence and development and low relative humidity reduce the incidence and development of plant diseases (Agrios 2005; Fry 1982). Similar observation should be conducted during the rainy season with high relative humidity.

\section{CONCLUSIONS}

Diseases found on physic nut in Lampung Province were cercospora leaf spot, alternaria leaf spot, fusarium wilt, and bacteial wilt. In addition, leaf malformation was also found in many locations. The symptom was first thought to be the result of a pathogenic virus attack. However, the symptom is not mechanically transmitted and the severity of diseases seemed to be correlated with the occurrence and population of mites. The disease severity of cercospora leaf spot and alternaria leaf spot was relatively low to moderate. Disease incidences of bacterial and fusarium wilts were also considered moderate.

Based on the distribution and intensity of the diseases, the most likely threatening disease in physic nut cultivation is bacterial wilt. Fusarium also caused wilt, but it was only found in one subdistrict with low incidence.

\section{ACKNOWLEDGMENTS}

The authors would like to thank the Southeast Asian Regional Centre for Tropical Biology (SEAMEO BIOTROP) Bogor for the financial support through DIPA 2007 and to Didik Purwanto and Tedy Achmad Rijaya for technical assistance in the fields and in the laboratory. 


\section{REFERENCES}

Agrios, G.N. 2005. Plant Pathology. $5^{\text {th }}$ ed. Elsevier Academic Press, Burlington, M.A., AS.

Anon.. 2007a. Lamsel - petani budidayakan jarak. Lampung Post, April 16, 2007.

Anon.. 2007b. Bahan bakar nabati: potensi Lampung 724,354 hektar. Lampung Post, January 24, 2007.

Banuwa, I.S. 2007. Prospek pengembangan tanaman jarak pagar (Jatropha curcas L.) di Provinsi Lampung. Paper presented at Seminar held in Bandar Lampung, May 29, 2009. 14 pp.

Barnett, H.L. and Hunter, B.B. 2001. Illustrated Genera of Imperfect Fungi. $5^{\text {th }}$ ed. MacMillan Pub. Co., New York.

Fry, W.E. 1982. Principles of Plant Disease Management. Academic Press, New York.

Hambali, E. Suryani, A., Dadang, Hariyadi, Hanafie, H., Reksowardojo, I.K., Rivai, M., Ihsanur, M., Suryadarma, P., Tjitrosemito, S., Soerawidjaja, T.H., Prawitasari, T., Prakoso, T., and W. Purnama. 2006. Jarak Pagar: Tanaman Penghasil Biodiesel. Penebar Swadaya, Depok.

Latha, P., V. Prakasam, A. Kamalakannan, C. Gopalakrishnan, T. Raguchander, M. Paramathma and R. Samiyappan. 2009. First report of Lasiodiplodia theobromae (Pat.) Griffon \& Maubl causing root and collar rot diseases of physic nut (Jatropha curcas L.) in India. Australasian Plant Disease Notes 4: $19-20$.

Lozano, J. A. D. 2007. Jatropha. www.gvedinternational.org/file_117/jatropha/ PDF.Eng.pdf. Accesed on February 18, 2008.

Prihandana, R. and R. Hendroko. 2006. Petunjuk Budi Daya Jarak Pagar. Agromedia Pustaka, Jakarta.

Republic of Indonesia, Department of Agriculture. 2006a. Penelitian dan Pengembangan Tanaman Jarak Pagar (Jatropha curcas L.) sebagai Bahan Pembuatan Enerji-bio di Indonesia perlu Mengikuti Peta Jalur yang Rasional. Info Tek Jarak Pagar (Jatropha curcas L.) Vol. 1 No. 1. in www.deptan.go.id/berita/ update27juli06/infotek/JP/No.201/2006.pdf. Accessed on January 17, 2006.

Republic of Indonesia Department of Agriculture. 2006b. Peluncuran Perdana Benih Unggul Jarak Pagar (Jatropha curcas L.). Info Tek Jarak Pagar (Jatropha curcas L.) Vol. 1 No. 7, 2006 in www.deptan. go.id/berita/update27juli06/infotek/JP/No.207/2006.pdf Accessed on January 17, 2006.

Semangun, H. 2000. Penyakit-penyakit Tanaman Perkebunan di Indonesia. Revised ed. Gadjah Mada University Press, Yogyakarta.

Sudradjat, H.R. 2006. Memproduksi Biodiesel Jarak Pagar, Solusi Hasilkan Biodiesel Bekualitas Tinggi. Penebar Swadaya, Depok.

Syah, A. N. A. 2006. Biodiesel Jarak Pagar, Bahan Alternatif yang Ramah Lingkungan. Agromedika Pustaka, Jakarta. 
Thank you for evaluating AnyBizSoft PDF Splitter.

A watermark is added at the end of each output PDF file.

To remove the watermark, you need to purchase the software from

http://www.anypdftools.com/buy/buy-pdf-splitter.html 